\title{
Forage kochia seed germination response to storage time and tem- perature
}

\author{
STANLEY G. KITCHEN AND STEPHEN B. MONSEN
}

Authors are botanists at the USDA-FS, Rocky Mountain Research Station, Shrub Sciences Laboratory, 735 North 500 East, Provo, Utah 84606.

\begin{abstract}
The Eurasian low-shrub, forage kochia [Kochia prostrata (L.) Shad.], was introduced into western North America for use in restoration of severely disturbed landscapes in arid and semiarid environments. Seed mature in late fall and are short-lived in typical warehouse conditions. In a preliminary, cold-temperature experiment $\left(2^{\circ} \mathrm{C}\right)$ using 3-month-old seed from 16 forage kochia accessions, mean germination time, expressed as days to $\mathbf{5 0 \%}$ germination, varied from 4 to 88 days. Follow up experiments using seed of 5 accessions tested the effects of storage time and temperature on seed viability and mean germination time and related this to field planting success. Sub-samples were air-dried and stored in plastic bags in a freezer, cold room, and lab $(-15,2$, and $20^{\circ} \mathrm{C}$ respectively). A fourth set of subsamples was stored in a shed with no temperature control (simulated warehouse storage). Seed were tested fresh and retested after 4, 8, 12, 24, and 36 months of storage. Mean viability decreased from $77 \%$ (range 66 to $93 \%$ ) for recently harvested seed, to 24 and $8 \%$ for lab- and shed-stored seed, after 36 months of storage. No significant change in viability was observed for cold room- and freezerstored seed. Across all accessions, cold temperature mean germination time (MGT) for recently harvested seed was 73 days (range 51 to 109 days). For each accession, germination occurred primarily over a 70 day period. Mean germination time decreased as storage time increased for lab- and shed-stored seed, varied unpredictably for cold room-stored seed, and remained unchanged for freezer-stored seed. Field germination using 1- and 2-year old lab- and shed-stored seed was significantly faster than that of same-aged cold room- and freezer-stored seed. The number of live seedlings 4 months after planting for cold room- and freezer-stored seed was $\mathbf{1 0 - f o l d}$ or greater than that of lab- and shed-stored seed. Thus a delayed, asynchronous cold-temperature germination pattern appears to be adaptive for forage kochia establishment. Cold, dry storage prevents loss of seed viability and preserves this desirable germination pattern.
\end{abstract}

Key Words: Kochia prostrata, prostrate summer cypress, germination rate, mean germination time, after-ripening, germination synchronization, cold-desert revegetation

This research was funded by the USDI-BLM, Idaho State Office, through Interagecy Agreement ID910. Special thanks are offered to Susan Meyer for assistance in data analysis and to Karl Soeresen, Darren Naillon, and Derek Hall for help in collecting and processing seeds and conducting laboratory experiments.

Manuscript accepted 16 Aug. 2000.
Resumen

El arbusto Euroasiático "Kochia forrajera" [Kochia prostata (L.) Shad], se introdujo en oeste de Norteamérica para usarlo en la restauración de paisajes severamente degradados de ambientes áridos y semiáridos. La semilla madura a finales de otoño y bajo las condiciones típicas de almacenamiento en bodega tiene una vida corta. En un experimento preeliminar, utilizando bajas temperaturas $\left(2^{\circ} \mathrm{C}\right)$, semilla de 3 meses de cosechada y proveniente de 16 entradas de "Kochia forrajera", se establecio que el tiempo promedio de germinación, experesado como días al $50 \%$ de semillas germinadas, varió de 4 a 88 días. En experimentos subsecuentes, usando semilla de 5 entradas, probamos los efectos del tiempo de almacenaje y la temperatura en la viabilidad de la semilla y el promedio del tiempo de germinación, y relacionamos esto con el éxito de establecimiento de las plantas en el campo. Submuestras se secaron con aire, se guardaron en bolsas de plástico y se almacenaron en: 1) congelador, 2) cuarto frío y 3) laboratorio $\left(-15,2\right.$ y $20^{\circ} \mathrm{C}$ respectivamente). Un cuarto grupo de submuestras se almaceno en un cobertizo sin control de temperatura (simulando las condiciones de bodega). Las semillas se evaluaron recién cosechadas y se reevaluaron a los $4,8,12,24$, y 36 meses de alacenamiento. El promedio de viabilidad disminuyó de $\mathbf{7 7 \%}$ (rango de 66 a $93 \%$ ) en semillas recién cosechadas a 24 y $8 \%$ en semillas almacenadas durante 36 meses en laboratorio y cobertizo. No se observaron cambios significativos en la viabilidad de semillas almacenadas en congelador y cuarto frío. La media generalde tiempo de germinación en temperaturas frías de todas de las entradas de "Kochia forrajera" fue de 73 días en semillas recién cosechadas (rango de 51 a 109 días). Para cada entrada de "Kochia forrajera" la germinación ocurrió después de 70 días. El tiempo promedio de germinación de semillas almacenadas en el laboratorio y cobertizo disminuyó conforme el tiempo de almacenamiento aumento, varió en forma inpredecibe para la semilla alamcenada en cuarto frío y permanecio sin cambios para la semilla almacenada en congelador. La germinación en campo de semillas almacenados por 1 y 2 años en el laboratorio y cobertizo fue significativamente más rápida que la de semilla almacenada durante el mismo tiempo en cuarto frío o congelador. El número de plántulas vivas (4 meses después de la siembra) de semillas alamcenadas en cuarto frío y congelador fue $\mathbf{1 0}$ veces o más que el de semillas almacenadas en laboratorio y cobertizo. Por lo tanto, un patrón de germinación retasado asincrónico de temperatura fría parece ser que se adapta para el establecimiento de "Kochia forrajera". El almacenamiento en condiciones secas y frías previene la perdida de viabilidad y conserva este patrón deseable de germinación. 
Many arid and semiarid rangelands of the western United States are becoming destabilized due to the interrelated effects of unsustainable grazing practices (Young 1994), introductions of old-world weeds (Peters and Bunting 1994), and changes in wildfire frequency (Whisenant 1990). Unchecked, these forces are causing the conversion of shrub and perennial grassesdominated communities to annuals-dominated communities with reduced resource values and serious management considerations. Restoring function and desired use to degraded rangelands can be accomplished by seeding adapted perennials capable of competing with weedy species and resprouting after fire. The need to develop plant materials endowed with these traits and the capacity to coexist with and complement remnant populations of native communities, is widely recognized.

Forage kochia [Kochia prostrata (L.) Shrad.], also known as prostrate summer cypress, is a polymorphic low-shrub native from the Mediterranean Basin to Siberia (Shishkin 1936). Baylan (1972) recognizes 2 subspecies: sp. virescens (Frenzl) Prat., commonly known as greenstem forage kochia, and sp. grisea Prat., or gray-stem forage kochia. Several germplasm introductions have been made to evaluate the utility of forage kochia for revegetation of severely disturbed arid and semi-arid sites in the western United States (McArthur et al. 1974, Frischknecht and Ferguson 1984, Blauer et al. 1993). Introductions have been evaluated for such traits as livestock and wildlife preference (Davis and Welch 1985), nutritional quality (Davis and Welch 1983, 1985), seed germination characteristics (Young et al. 1981, Waller et al. 1983, Briede and McKell 1992, Stewart 1998), establishment and competitive attributes (Stevens and Van Epps 1984, McArthur et al. 1990, Monsen and Turnipseed 1990, Stevens and McArthur 1990, McArthur et al. 1996, Harrison et al. 2000), and salinity tolerance (Francois 1976, Romo and Haferkamp 1987). Studies demonstrate that forage kochia is well suited for a variety of soil types on cold-desert rangelands receiving 150-300 mm annual precipitation. A single cultivar, 'Immigrant', (sp. virescens) was released after demonstrating wide spread adaptability, forage quality, and productivity (Stevens et al. 1985). Several thousand kilograms of seed of this cultivar are planted on rangelands most years.

Forage kochia grows throughout the summer, flowering indeterminately from June through September (Shishkin 1936, Baylan 1972). Fruits usually mature by the middle of October (Waller et al. 1983, Stewart 1998) and are commonly harvested from October through January. Subsequently, current-year seed is sometimes not available in time for fall and early winter revegetation projects. Forage kochia stand establishment from seed stored for 1 or more years in typical warehouse conditions is generally poor. This is due in part to the short shelf-life for seed of this species. Shelf-life can be extended by adequate pre-drying and by storage in sealed containers at low temperatures (Young et al. 1981, Jorgensen and Davis 1984, Stewart 1998). However, a lack of stand establishment success using high-viability, stored seeds is more difficult to explain. Low seed vigor has been proposed as one possible explanation (Haferkamp et al. 1990). In this work, we provide evidence to support an alternative explanation.

For best emergence, forage kochia seed must germinate at or near the soil surface. In the cold-desert environments to which this species is adapted, soil temperature and moisture conditions favorable for surface germination and seedling growth occur most dependably during brief periods in late winter and early spring. Seed that germinate at other times (e.g. too late or too early) have a higher risk of mortality than do seed with proper germination timing. Therefore, we attempt to test the

Table 1. Forage kochia accessions by plant introduction number, location and soil type of original collection, and cold temperature $\left(2^{\circ} \mathrm{C}\right)$ mean germination time (MGT), expressed as days to $50 \%$ germination of viable seeds. All seed was 3 months old except for accession 314929 which was 1 year old. Means followed by the same letter are not significantly different at the $p<0.05$ level (Tukey).

\begin{tabular}{|c|c|c|c|}
\hline \multirow[b]{2}{*}{ P.I. No. ${ }^{a}$} & \multicolumn{2}{|l|}{ Original Collection Information ${ }^{\mathrm{b}}$} & \multirow[b]{2}{*}{ MGT } \\
\hline & Location & Soil Type & \\
\hline & & & (days) \\
\hline ----- & Inner Mongolia, Peoples Republic of China & Unknown & $3.7 \mathrm{j}$ \\
\hline $314929^{\mathrm{c}, \mathrm{d}}$ & Stavropol', Russia "Immigrant" & Sandy & $11.2 \mathrm{j}$ \\
\hline 330708 & Rashat, Iran & Unknown & $41.9 \mathrm{hi}$ \\
\hline $343101^{\mathrm{d}}$ & Kyrgyzstan & Unknown & 32.1hi \\
\hline 356817 & Akt'ubinsk, Kazakhstan & Salty & $44.7 \mathrm{gh}$ \\
\hline $356818^{\mathrm{d}}$ & Akt'ubinsk, Kazakhstan & Clay & 41.5hi \\
\hline 356819 & Akt'ubinsk, Kazakhstan & Salty & 48.7efgh \\
\hline 356820 & Akt'ubinsk, Kazakhstan & Sandy & 53.1 defg \\
\hline 356821 & Akt'ubinsk, Kazakhstan & Salty & 50.9efgh \\
\hline 356822 & Akt'ubinsk, Kazakhstan & Clay & $55.6 \mathrm{cdef}$ \\
\hline 356823 & Akt'ubinsk, Kazakhstan & Sandy & 58.5bcde \\
\hline 356824 & Akt'ubinsk, Kazakhstan & Salty & $67.0 \mathrm{~b}$ \\
\hline 356825 & Akt'ubinsk, Kazakhstan & Sandy & $66.4 b c$ \\
\hline $356826^{\mathrm{d}}$ & Akt'ubinsk, Kazakhstan & Salty & $88.3 \mathrm{a}$ \\
\hline $358941^{\mathrm{d}}$ & Stavropol', Russia & Sandy & $47.6 \mathrm{fgh}$ \\
\hline 422519 & Unknown & Unknown & $61.2 \mathrm{bcd}$ \\
\hline
\end{tabular}

${ }^{\mathrm{a}}$ The PI number is the USDA plant inventory number. The first 2 accessions are sp. virescens and the rest belong to sp. grisea.

${ }^{\mathrm{B}}$ This information came with original seed packets from the USDA ARS Western Regional Plant Introduction Station in Pullman, Washington. Locations should be taken as general areas. The collections from Akt'ubinsk are regional collections taken from the Aral Sea to the Ural Mountains. Those from Stavropol' came from a botanical garden.

'The cultivar 'Immigrant' (Stevens et al. 1985).

dAccessions selected for the storage experiments. 
had not been collected at the Boise common garden, 1-year-old seed of Immigrant forage kochia (sp. virescens) was secured and included in the experiment. For each accession, 4 replications of 50 seeds each were placed in $15 \times 100 \mathrm{~mm}$ plastic petri dishes on top of 2 germination blotters (Anchor Paper Company, St. Paul, Minn.) moistened to saturation with tap water. Petri dishes were arranged randomly in a cardboard box. The box was enclosed in a plastic bag to retard desiccation, and placed in a walk-in cold room at $2^{\circ} \mathrm{C}$. Water was added periodically to maintain blotter water content at near saturation levels. Seed were examined and germinants were counted and removed from the petri dishes on a weekly basis for 112 days. Seed were classified as germinated when radicles had elongated at least $3 \mathrm{~mm}$ and demonstrated a positive gravitropic response. Most germinants were also at least partially uncoiled. At the end of 112 days, the box was moved to a germination chamber set at $15 / 25^{\circ} \mathrm{C}$ (12 hour alternating) for 3 additional days. After final germination counts were made, an embryo integrity (squish) test confirmed the absence of remaining viable (dormant) seed. Viability percentages and mean germination time values were calculated for each replication.

\section{Storage Experiments}

Seed of 4 experimental lines were harvested from a nursery site in Spanish Fork, Utah (Latitude and Longitude; $39^{\circ} 40^{\prime}$ North $111^{\circ} 5^{\prime}$ West) during October and November 1992 (Table 1). Length of harvest period was due to variability in ripening rates among accessions. Ripened fruits were easily collected by beating fruit-bearing stems against the edge of hand-held hoppers with badminton rackets. Harvested fruits were spread on tables to a depth of $10 \mathrm{~cm}$ for $10+$ days prior to further processing. Temperatures varied between 15 and $25^{\circ} \mathrm{C}$, and though not measured, relative humidity was sufficiently low to allow drying to occur. Subsequently, inert material and a portion of unfilled fruits were removed from each lot using a 2-screen fanning mill. Cleaned seed (fruits) were stored in cloth bags for approximately 1 month $\left(15\right.$ to $\left.25^{\circ} \mathrm{C}\right)$ before further processing. A fifth accession, non-certified Immigrant, was acquired from a commercial source and had been collected in November 1992 from a USDI-BLM planting located $15 \mathrm{~km}$ northeast of Milford, Utah.

In December, seed of all 5 accessions were oven-dried at $35^{\circ} \mathrm{C}$ for 72 hours and subdivided into 4 equal sublots. Each sublot was placed in a labeled plastic bag closed with a rubber band. One sublot (bag) for each accession was placed inside each of 4 larger plastic bags, also closed with a rubber band. One of each of these bags was stored for 36 months in: 1) the laboratory at room temperature $\left.\left(20^{\circ} \mathrm{C}\right) ; 2\right)$ the walk-in cold room $\left.\left(2^{\circ} \mathrm{C}\right) ; 3\right)$ a freezer $\left(-15^{\circ} \mathrm{C}\right)$; and 4$)$ a shed in Provo, Utah with no temperature control (to simulate warehouse storage). To determine seed water content immediately after processing and again after 8 months of storage, subsamples of approximately $20 \mathrm{~g}$ were weighed, oven dried for 24 hours at $65^{\circ} \mathrm{C}$, and reweighed. Mean water content for dried seed before storage was $4.1 \%$. There was no significant change in water content after 8 months of storage for all storage treatments $($ mean $=3.9 \%)$.

Germination procedures followed those used in the preliminary experiment with the following exceptions: 1) 25 instead of 50 seeds per replication were used and 2) final incubation temperature was $10 / 20^{\circ} \mathrm{C}$ instead of $15 / 25^{\circ} \mathrm{C}$. These changes were intended to make the germination environment less favorable for potential seed pathogens. Each accession was tested fresh (December 1992) and each accession/storage combination was tested after $4,8,12,24$, and 36 months of storage.

\section{Field Trials}

A fallowed agricultural field with uniform soil and topography was selected near American Fork, Utah (Latitude and Longitude; $40^{\circ} 20^{\prime}$ North $111^{\circ} 50^{\prime}$ West; elev. $1,380 \mathrm{~m}$ ) as a site for field germination and seedling establishment experiments. The site was tilled each fall prior to planting dates (30 November 1993 and 2 December 1994). Litter cover was less than $5 \%$, ensuring good seed contact with mineral soil. Results were interpreted in light of ambient temperature data for the Utah Lake Lehi weather station (NOAA 1993, 1994, 1995) located $8 \mathrm{~km}$ west of the planting site (same approximate elevation). When data were incomplete for any month, estimates were made using data from the Vernon and Timpanogos Cave sites, 48 and $8 \mathrm{~km}$ distant from the planting site.

Only Immigrant seed was used for these field studies. Seed had experienced 1 and 2 years of storage prior to planting. In preparation, each year twelve, $0.2-\mathrm{g}$ and three, 2-g subsamples were weighed from each of the 4 Immigrant sublots (storage treatments). The twelve, 0.2-g subsamples of approximately 160 seeds each (150 viable seeds prior to storage) were enclosed in marked $10 \times 10 \mathrm{~cm}$ square nylon-mesh bags. Bags were randomly sorted into 12 sets, each set including 1 bag from each storage treatment.

In 1993, each set of bags was buried under 1.0 to $1.5 \mathrm{~cm}$ of soil and marked with a $75-\mathrm{cm}$ survey flag to facilitate detection in snow. Each group of bags was placed under a $20 \mathrm{~cm}$ (diameter) wiremesh cone buried $3 \mathrm{~cm}$ deep to discourage rodents. Cones were arranged in a 2 by 6 grid with $10-20 \mathrm{~cm}$ inter-cone spacing. We used similar procedures in 1994, however, bags were not buried in soil and cones were not used. Instead, bags were firmly pressed into the soil surface and covered with 1-2 $\mathrm{cm}$ of straw. This change was made to simplify extraction of bags from frozen soil. This mulch was held in place by 2 cris-crossed layers of pine stakes $(2 \times 4 \times 35 \mathrm{~cm})$ placed horizontally with 12 to $15 \mathrm{~cm}$ spacing between stakes. No rodent predation was encountered either year.

Each year, 3 sets (replications) of 4 bags each were randomly selected and retrieved from the site 1 and 2 months following burial. Retrieved bags were packed in loose snow and taken directly to the laboratory for processing. There, soil and ice were gently washed from each bag before opening. We then opened bags and determined germination status for each seed. Average time from bag retrieval to final seed evaluation was 2 to 3 hours. Due to rapid germination associated with unseasonably warm temperatures in December and January (Fig. 1), 6 sets of bags remained unused both years.

The 2-g samples were planted on twelve, $1.0 \times 0.5 \mathrm{~m}$ plots arranged in a randomized block design each year. Planting consisted of hand broadcasting seed onto the appropriate plot and lightly raking over the entire plot to improve soil/seed surface contact and to anchor the seeds to the plots. Planting dates were the same as burial dates for the retrieval experiments. We determined the number of forage kochia seedlings per plot approximately 4 months after planting (early April), both years. At this time, the soil surface was dry and crusted and surviving seedlings had reached or passed the 6-leaf stage.

Percentage data (seed viability in storage experiments and seed germination and seedling survival in field experiments) were arcsine transformed for statistical analysis. Results were analyzed using the GLM procedure (SAS 1998) to test for effects of storage treatment and time on 


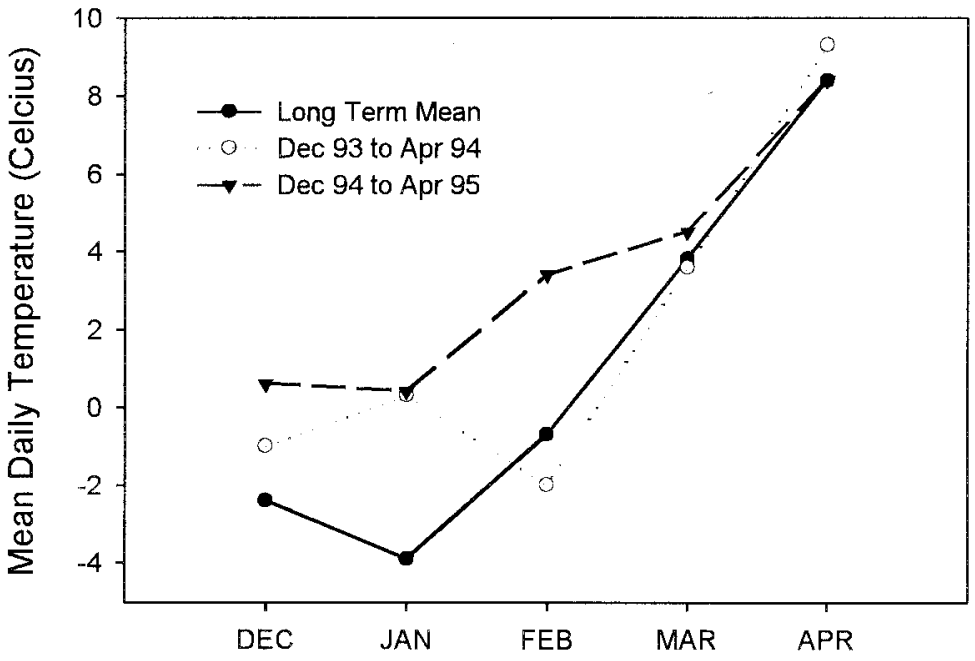

Fig. 1. Mean daily temperatures for the months of December to April for the Utah Lake Lehi weather station. Values for the winters of 1993-1994 and 1994-1995 are compared to the long-term mean (1961-1990) for the site (NOAA 1993, 1994, 1995). When data were missing, means were estimated using data from the Vernon and Timpanogos Cave stations.

viability percentage and cold mean germination time in laboratory experiments, and field germination and seedling survival in field experiments. Significant differences among accession and treatment means were determined using the Tukey-Kramer (Tukey) multiple means comparison test.

\section{Results}

Mean germination time (MGT) for the 15 experimental lines of the preliminary experiment ranged from 3.7 to 88.3 days (Table 1). The fastest germination rates belonged to the accession originally collected in the Inner-Mongolia region of the
People's Republic of China (MGT = 3.7 days) and to 1 year-old Immigrant seed $(\mathrm{MGT}=11.2$ days $)$. Mean germination time for the remaining accessions (all recently harvested seed) was 54.1 days. seed after 112 days of chilling was $29 \%$ $($ MGT $=88.3$ days $)$. Accessions selected for the storage experiments represented nearly the full range in observed mean germination time values.

\section{Storage Experiments}

Mean viability of recently harvested seed was $77 \%$ (range 66 to $93 \%$ ). After 12 months storage, viability of lab- and shedstored seed $(71 \%)$ was significantly lower Maximum percentage of ungerminated

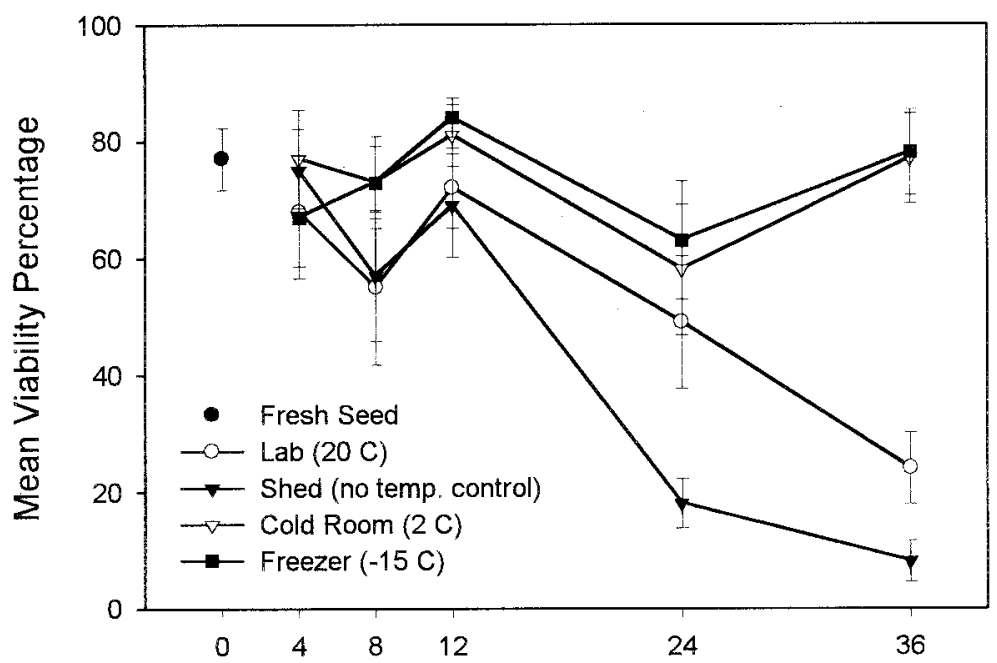

Fig. 2. Mean viability for 5 accessions of forage kochia tested fresh and in response to dry storage treatments. $(\mathrm{p}<0.05)$ than that of cold room- and freezer-stored seed $(83 \%)$. After 36 months of storage, viability of lab- and shed-stored seed decreased to 24 and $8 \%$, respectively (Fig. 2). Viability percentages for 36-month old cold room- and freezerstored seed were not significantly different than those of recently harvested seed. However, viability of 24-month old cold room- and freezer-stored seed was significantly lower than that of either recently harvested or 36-month old seed for 4 of 5 accessions. Because viability can not increase through time, the observed increase is best explained as differential selection among test dates for filled fruits. This is not surprising in as much as fill for intact fruits can be difficult to detect. Only with the commercially collected and conditioned Immigrant seed were we able to consistently eliminate most empty fruits by visual inspection. Within test dates, treatment-related differences in viability estimates were similar for all accessions (including Immigrant), suggesting that within-test date seed selection was much more consistent than among-test date selection. All ungerminated, viable seed germinated within a few days after exposure to warmer germination temperatures $\left(10 / 20^{\circ} \mathrm{C}\right)$ at the end of the 112-day cold treatment.

Although similar in duration (approximately 70 days), the primary period of germination for recently harvested seed varied considerably among accessions (Fig. 3). Mean germination time (MGT) was 73 days (range $=51$ to 109 days). As in the preliminary experiment, significant among-accession differences in germination rate were observed (Table 2). Mean germination times for these accessions were greater for this experiment than in the preliminary experiment, suggesting differences in afterripening and/or site conditions during seed maturation. This difference was most pronounced for seed of Immigrant (MGT = 11 vs. 70 days). However, Immigrant seed in the preliminary experiment was 1-year-old, therefore, comparisons between that seed and recently harvested seed of the storage experiment would be invalid. A more appropriate inter-experimental comparison for Immigrant seed germination rate would be between results of the preliminary experiment and those derived after 12 months of lab- or shed-storage (MGT $=13$ and 15 days, respectively).

After 8 months of storage, mean germination times for lab-, shed-, and cold room-stored seed $(17,19$, and 22 days, respectively) was significantly shorter 
Table 2. Cold temperature $\left(2^{\circ} \mathrm{C}\right)$ mean germination time (days to $50 \%$ germination of viable seeds) for 5 accessions of forage kochia tested fresh and after 4-36 months dry storage in a lab $\left(20^{\circ} \mathrm{C}\right)$, cold room $\left(2^{\circ} \mathrm{C}\right)$, freezer $\left(-15^{\circ} \mathrm{C}\right)$, and shed with no temperature control. Among accessions for fresh seed, and within accessions and storage period for stored seed, means followed by the same letter are not significantly different at the $p<0.05$ level (Tukey).

\begin{tabular}{|c|c|c|c|c|c|c|}
\hline \multirow{3}{*}{$\begin{array}{l}\text { Accession No./ } \\
\text { Storage } \\
\text { Treatment }\end{array}$} & \multirow[b]{3}{*}{ Fresh } & \multirow{2}{*}{\multicolumn{5}{|c|}{ Mean Germination Time (days to $50 \%$ germination) }} \\
\hline & & & & & & \\
\hline & & 4 & 8 & 12 & 24 & 36 \\
\hline & $\ldots$ & -- & $-\cdots($ & -- & - - & - \\
\hline 314929 (Immigrant) & $70 \mathrm{~b}$ & & & & & \\
\hline $\mathrm{Lab}$ & & $47 \mathrm{~b}$ & $16 \mathrm{~b}$ & $13 \mathrm{c}$ & $11 \mathrm{~b}$ & $6 \mathrm{~b}$ \\
\hline Cold Room & & $44 \mathrm{~b}$ & $26 \mathrm{~b}$ & $36 \mathrm{~b}$ & $58 \mathrm{a}$ & $16 \mathrm{~b}$ \\
\hline Freezer & & $71 \mathrm{a}$ & $70 \mathrm{a}$ & $70 \mathrm{a}$ & $67 \mathrm{a}$ & $76 a$ \\
\hline Shed & & $59 \mathrm{a}$ & $19 \mathrm{~b}$ & $15 \mathrm{bc}$ & $21 \mathrm{~b}$ & $15 b$ \\
\hline 343101 & $51 \mathrm{c}$ & & & & & \\
\hline Lab & & $40 \mathrm{a}$ & $12 \mathrm{~b}$ & $17 \mathrm{~b}$ & $12 \mathrm{~b}$ & $8 \mathrm{~b}$ \\
\hline Cold Room & & $21 \mathrm{~b}$ & $14 \mathrm{~b}$ & $24 \mathrm{~b}$ & $46 \mathrm{a}$ & $28 \mathrm{~b}$ \\
\hline Freezer & & $54 \mathrm{a}$ & $56 \mathrm{a}$ & $64 \mathrm{a}$ & $55 \mathrm{a}$ & $59 \mathrm{a}$ \\
\hline Shed & & $49 \mathrm{a}$ & $17 \mathrm{~b}$ & $13 \mathrm{~b}$ & $12 \mathrm{~b}$ & $9 \mathrm{~b}$ \\
\hline 356818 & $53 \mathrm{c}$ & & & & & \\
\hline $\mathrm{Lab}$ & & $43 a b$ & $21 \mathrm{~b}$ & $23 b$ & $13 \mathrm{~b}$ & $16 \mathrm{~b}$ \\
\hline Cold Room & & $26 \mathrm{~b}$ & $19 \mathrm{~b}$ & $37 \mathrm{~b}$ & $51 \mathrm{a}$ & $31 \mathrm{~b}$ \\
\hline Freezer & & $49 \mathrm{a}$ & $49 \mathrm{a}$ & $63 \mathrm{a}$ & $58 \mathrm{a}$ & $67 \mathrm{a}$ \\
\hline Shed & & $59 \mathrm{a}$ & $20 \mathrm{~b}$ & $16 \mathrm{~b}$ & $18 \mathrm{~b}$ & $19 \mathrm{~b}$ \\
\hline 356826 & $109 a$ & & & & & \\
\hline $\mathrm{Lab}$ & & $61 \mathrm{~b}$ & $17 \mathrm{~b}$ & $7 \mathrm{c}$ & $11 \mathrm{~b}$ & $6 \mathrm{c}$ \\
\hline Cold Room & & $62 \mathrm{~b}$ & $31 \mathrm{~b}$ & $66 \mathrm{a}$ & $86 \mathrm{a}$ & $37 \mathrm{~b}$ \\
\hline Freezer & & $96 a$ & $93 \mathrm{a}$ & $87 a$ & $90 \mathrm{a}$ & $106 \mathrm{a}$ \\
\hline Shed & & $78 \mathrm{ab}$ & $21 \mathrm{~b}$ & $13 b$ & $10 \mathrm{~b}$ & ---- \\
\hline 358941 & $81 \mathrm{~b}$ & & & & & \\
\hline Lab & & $55 \mathrm{ab}$ & $20 \mathrm{~b}$ & $12 \mathrm{~b}$ & $12 \mathrm{~b}$ & $6 \mathrm{~b}$ \\
\hline Cold Room & & $40 \mathrm{~b}$ & $20 \mathrm{~b}$ & $23 b$ & $63 \mathrm{a}$ & $8 \mathrm{~b}$ \\
\hline Freezer & & $69 \mathrm{a}$ & $87 \mathrm{a}$ & $67 \mathrm{a}$ & $76 a$ & $75 \mathrm{a}$ \\
\hline Shed & & $62 \mathrm{a}$ & $18 \mathrm{~b}$ & $14 \mathrm{~b}$ & $12 \mathrm{~b}$ & $11 \mathrm{~b}$ \\
\hline
\end{tabular}

than those observed for recently harvested seed (Fig. 4). Within-accession changes and among-accession differences in mean germination time were small and essentially insignificant for lab- and shed-stored seed in response to longer periods of storage. Mean germination time for cold room-stored seed (all 5 accessions) changed unpredictably over the duration of the experiment with values significantly higher ( $p>0.05)$ after 12 and 24 months (37 and 61 days, respectively), but not after 36 months (24 days) when compared to those observed after 8 months ( 22 days) of storage. Across all storage periods, differences in the observed mean germination time for freezer-stored seed were not significantly different than that of fresh seed. Although initial (recently harvested seed) mean germination times varied more than 2 -fold among accessions, relative differences in treatment effects are similar among accessions (Table 2). For all accessions, freezer storage was the only method found effective in preserving original germination patterns through 36 months of storage.

\section{Field Trials}

Laboratory germination results generally supported results observed for field experiments. For both years of burial, significantly higher percentages of viable seed had not yet germinated 1 month after planting for cold room- and freezer-stored seed than for lab- and shed-stored seed (Table 3). Nearly all viable seed from all 4 storage treatments had germinated by the second retrieval date. Unseasonably warm temperatures during December and January both years (1993-94 and 1994-95; Fig. 1) undoubtedly allowed germination to occur at a more rapid rate than might have been observed under

Table 3. Field germination of Immigrant forage kochia seed 1 and 2 months after planting as affected by storage treatment. Seed planted in 1993 and 1994 had been stored dry for 1 and 2 years before planting. Data are shown as mean number of viable seed ungerminated and percent ungerminated based on total viable seed (in parentheses). Within rows, means followed by the same letter are not significantly different at the $p<0.05$ level (Tukey).

\begin{tabular}{|c|c|c|c|c|c|}
\hline \multirow{2}{*}{$\begin{array}{l}\text { Year of } \\
\text { Planting }\end{array}$} & \multirow{2}{*}{$\begin{array}{l}\text { Months after } \\
\text { Planting }\end{array}$} & \multicolumn{4}{|c|}{ Storage Treatment } \\
\hline & & $\mathrm{Lab}$ & Shed & Cold Room & Freezer \\
\hline & & No. $(\%)$ & No. $(\%)$ & No. $(\%)$ & No. $(\%)$ \\
\hline \multirow[t]{2}{*}{93} & 1 & $60(51) \mathrm{b}$ & $61(49) \mathrm{b}$ & $138(92) \mathrm{a}$ & $135(92) \mathrm{a}$ \\
\hline & 2 & $18(15) \mathrm{ab}$ & $6(8) b$ & $26(17) \mathrm{a}$ & $32(21) \mathrm{a}$ \\
\hline \multirow[t]{2}{*}{94} & 1 & $3(4) b$ & $3(22) b$ & $113(76) \mathrm{a}$ & $124(84) \mathrm{a}$ \\
\hline & 2 & $0 \mathrm{~b}$ & $\mathrm{Ob}$ & $6(4) a b$ & $20(7) \mathrm{a}$ \\
\hline
\end{tabular}

colder conditions.

Mean numbers of live seedlings counted on the $0.5 \mathrm{~m}^{2}$ emergence plots for cold room- and freezer-stored seed were approximately 10 -fold those counted for lab- and shed-stored seed the first year (Table 4). Differences in second-year results are greater than those of the first year. This is true whether expressed as the absolute number of seedlings counted or as a percentage of viable seed planted as estimated by retrieval experiments. Differences between cold room- and freezer-stored seed and between lab- and shedstored seed were not significant either year.

\section{Discussion}

Forage kochia is well adapted to the sometimes severe and generally variable weather conditions found in the colddeserts of western North-America (McArthur et al 1974, Pendleton et al. 1992, McArthur et al. 1996). Although successful seedling establishment may require some disturbance in perennial communities (McArthur et al. 1990, Stevens and McArthur 1990, Harrison et al. 2000) new seedlings are observed near established plants most years. Late-season seed maturation and a delayed/asynchronous germination pattern in cold temperatures result in a high probability that some fraction of seed will germinate during a time favorable for establishment success. Germination that is too early or too uniform places seedlings at risk to conditions unfavorable for survival. The timing of these late winter/early spring 'windows of opportunity' varies annually, favoring the selection of a bet-hedging germination strategy (Phillipi and Seger 1989). Asynchronous cold-temperature germination functions as a bet-hedging strategy for forage kochia. Changes in seed germinability in dry storage, also known as dry afterripening, are common and are generally expressed as loss of innate dormancy, loss of light and temperature sensi- 


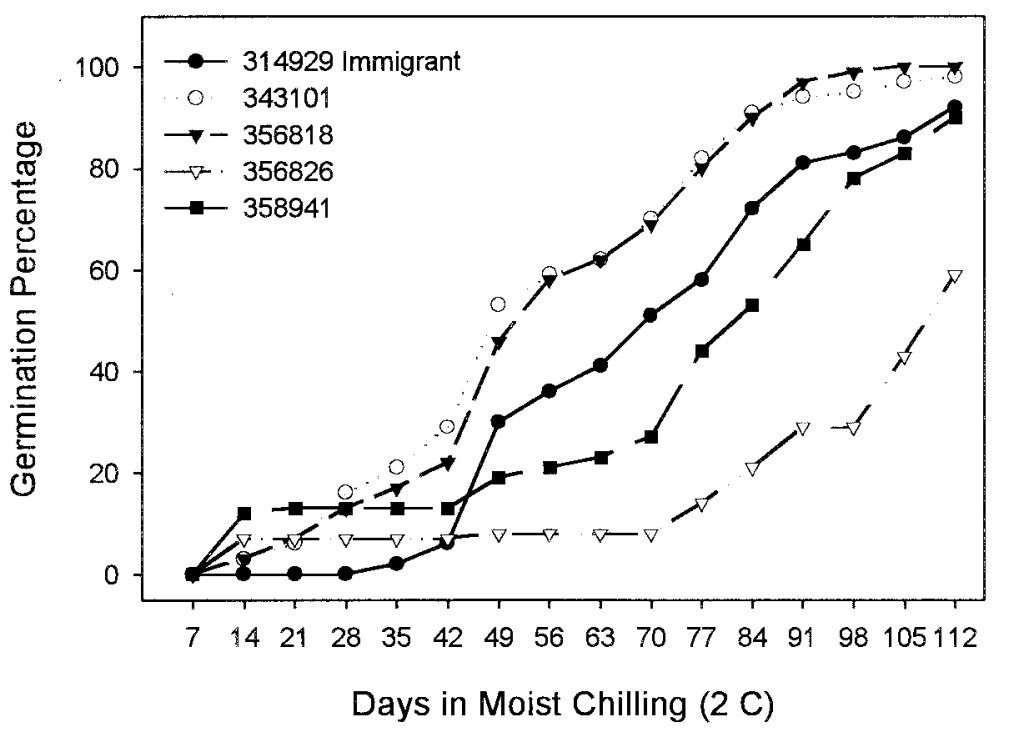

Fig. 3. Time course germination plots for 5 recently-harvested accessions of forage kochia at $\mathbf{2}^{\circ} \mathbf{C}$.

tivity, and/or changes in germination rate (Bewley and Black 1982). After-ripening is uni-directional and temperature dependent. Therefore, it can be expected that the process of after-ripening is greatly slowed, or even arrested, at freezing temperatures. Our data suggest that this is the case for forage kochia seed.

Conversely, we might expect seed stored at constant warm temperature to show a relatively rapid, continuous change in germinability, or in our case, decrease in mean germination time (MGT). Seed stored in the lab for the first 8 months at room temperature followed just such a pattern. A leveling off of MGT after 8 months of storage suggests that warmstored seed reached a threshold in germination rate. Temperatures for shed-stored seed were controlled by ambient temperatures which fluctuate daily and seasonally. For much of the first 4 months of storage (January-April) ambient temperatures were cold, often sub-freezing (Fig. 1), resulting in slower rates of afterripening. We might predict that 4-month MGT for

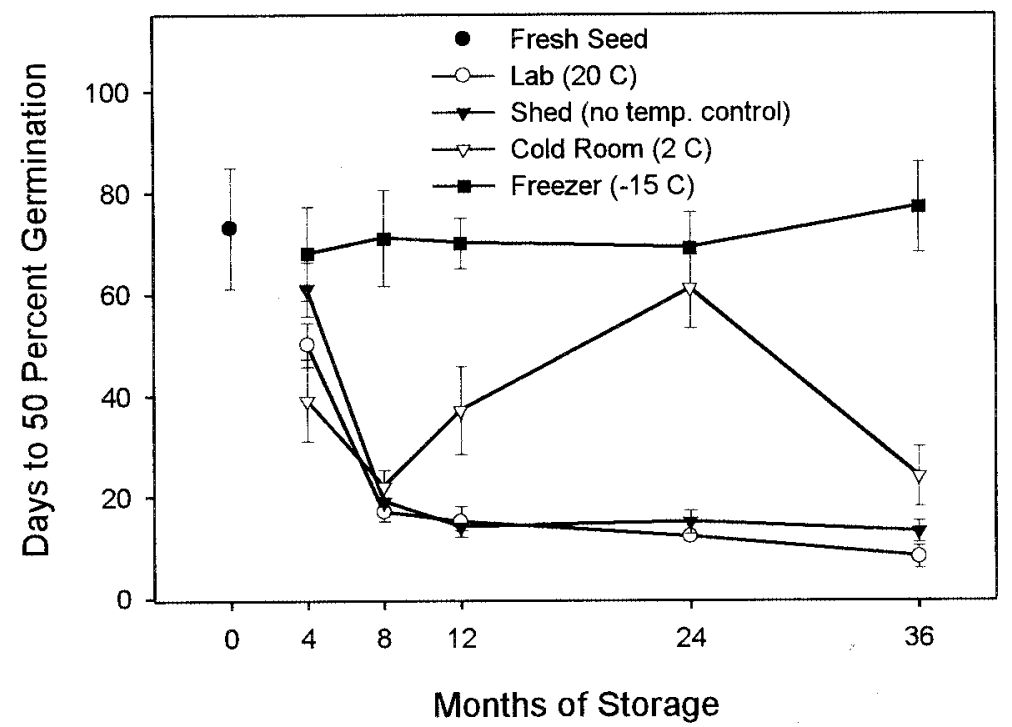

Fig. 4. Mean germination time (days to $\mathbf{5 0 \%}$ germination) for 5 accessions of forage kochia as affected by storage location (temperature) and time. this storage treatment would have to be intermediate to that of freezer- and labstored seed. This was indeed the case (Fig. 3 ). In the time period between 4 and 8 months of storage (May-August), seed in the shed storage treatment were exposed to ambient temperatures higher than in any other storage treatment. Subsequently, changes related to after-ripening should have been accelerated for this storage treatment during this time. Not surprisingly, the change in mean germination time for all accessions in the 4 to 8 month interval was greater for this storage treatment than for any other. From this point on, mean germination time for shed-and labstored seed did not differ significantly with length of storage.

Accounting for the changes in mean germination time (MGT) for cold roomstored seed over time is more difficult. Because after-ripening is temperature dependent, we expected changes in MGT for cold room-stored seed to be slower than those observed for lab-stored seed. This was not the case for the first 8 months of storage suggesting that another process, perhaps akin to prechill (stratification), may have been responsible. However, prechill treatments are generally effective only when seed have imbibed water. Our seed remained dry through the storage treatment. Waller et al. (1983) reported that after 3 months dry storage, forage kochia seed stored at $4^{\circ} \mathrm{C}$ produced germination percentages higher than seed stored at either -18 or $21^{\circ} \mathrm{C}$, also suggesting an accelerated rate of after-ripening in near freezing temperatures. Increases in MGT associated with 12 and 24 months of storage and subsequent decrease observed with the 36 month treatment are puzzling and identifying a process or processes responsible for these unexpected reversals will not be easy.

Among accession differences in MGT for freshly collected seed were significant and likely adaptive, probably reflecting climatic differences in the Eurasian origins of the respective accessions. We have insufficient knowledge concerning those origins to speculate on the significance of those differences including the unusually rapid cold germination rate of 3 -month old seed of the Chinese accession (Table 1). Waller et al. (1983) observed differences in germination $\left(15 / 25^{\circ} \mathrm{C}\right.$ ) for 2 accessions of forage kochia (one of each subspecies) as affected by harvest date, drying method, and storage temperature. They concluded that, based on their data, the gray-stem variety (sp. grisea) had better germination characteristics than the red- 
Table 4. Number of forage kochia seedlings 5 months after planting as affected by seed storage treatment. Seed planted in 1993 and 1994 had been stored for 1 and 2 years. Numbers in parentheses are live seedlings expressed as a percent of viable seed planted. Within rows, means followed by the same letter are not significantly different at the $p<0.05$ level (Tukey).

\begin{tabular}{lllll}
\hline \hline $\begin{array}{l}\text { Year of } \\
\text { Planting }\end{array}$ & Lab & \multicolumn{2}{c}{ Storage Treatment } & \\
\hline \multirow{2}{*}{1993} & No. $(\%)$ & No. $(\%)$ & Cold Room & Freezer \\
1994 & $30(2) \mathrm{b}$ & $22(2) \mathrm{b}$ & $240(16) \mathrm{a}$ & No. $(\%)$ \\
\hline & $10(1) \mathrm{b}$ & $2(2) \mathrm{b}$ & $278(20) \mathrm{a}$ & $207(14) \mathrm{a}$ \\
\hline
\end{tabular}

stem variety (sp. virescens) and suggest that it would therefore be preferred for revegetation. Our study significantly expands understanding of forage kochia intra-specific variability in germination behavior both because of the quantity of germplasm tested and because of the exposure of that germplasm to treatments relevant to storage and seedbed environments. We contend that the germination patterns for recently collected seeds of all accessions that we have tested (with the likely exception of the Chinese accession) are broad enough for successful establishment in the arid/semiarid West. Further speculation concerning how adaptive the germination timing of any one accession might be for specific environments, based on our data, would be inappropriate. Changes in MGT in storage were similar for all accessions even though initially values varied 2-fold. Ultimately, MGT for all accessions dropped to between 21 and 12 days after 8 months of lab or shed storage suggesting that similar storage treatments are unsuitable for any and all accessions to preserve a germination profile suitable for wildland plantings.

Storage treatment related differences in laboratory germination trials were largely matched by field seed retrieval experiments. In addition, successful seedling establishment was significantly greater for cold room- and freezer-stored seed; those treatments with the slowest MGT in laboratory experiments after 12 and 24 months (Table 2).

\section{Conclusions}

Data from this study support the conclusion that an altered germination timing regime may be responsible for forage kochia seeding failure using after-ripened seed of known high viability. We observed that low temperature germination is delayed and asynchronous for recently harvested seed and that germination rate increases dramatically with after-ripening. We also observed poor field performance of after-ripened seed. With this study we provide additional evidence of why forage kochia seed need to be dried to less than $7 \%$ moisture, sealed in water tight containers, and stored at temperatures below $5^{\circ} \mathrm{C}$ (Jorgensen and Davis 1984, Stewart 1998) when not planted soon after harvest. germination patterns we observed for cold room-stored seeds, we believe that there may be an additional advantage to storage at temperatures below freezing. Finally, afterripened seed with rapid germination may be suitable for spring or summer plantings where supplemental irrigation is available.

\section{Literature Cited}

Baylan, G.A. 1972. Prostrate summer cypress and its culture in Kirghizia. Isdatel'stvo, Frunze, Kirghizistan (Translated from Russian, 1979, USDA and Nat. Sci. Foundation, Washington, D.C.). 295 p.

Bewley, J.D. and M. Black. 1982. Physiology and biochemistry of seeds. Vol. 2. SpringerVerlag, Berlin.

Blauer, A.C., E.D. McArthur, R. Stevens, and S.D. Nelson. 1993. Evaluation of roadside stabilization and beautification plantings in south-central Utah. USDA-FS, Res. Pap. INT-462, Ogden, Ut. 65 p.

Briede, J.W. and C.M. McKell. 1992. Germination of seven perennial land species, subjected to soil moisture stress. J. Arid Environ. 23:263-270.

Davis, J.N. and B.L. Welch. 1983. Seasonal variation in crude protein content of Kochia prostrata (L.) Schrad, p. 145-149. In: A.R. Tiedemann, E.D. McArthur, H.C. Stutz, R. Stevens, and K.L. Johnson (compilers), Proc.-symposium on the biology of Atriplex and related chenopods. USDA U.S. Forest Serv. Gen. Tech. Rep. INT-172. Ogden, Ut.

Davis, J.N. and B.L. Welch. 1985. Winter preference, nutritive value, and other range use characteristics of Kochia prostrata (L.) Schrad. Great Basin Nat. 45:778-783.

Francois, L.E. 1976. Salt tolerance of prostrate summer cypress (Kochia prostrata). Agron. J. 68:455-456.

Frischknecht, N.C. and R.B. Ferguson. 1984. Performance of Chenopodiaceae species on processed oil shale, p. 293-297. In: A.R. Tiedemann, E.D. McArthur, H.C. Stutz, R. Stevens, and K.L. Johnson (compilers), Because of the unpredictable changes in
Proc.-Symposium on the biology of Atriplex and related chenopods. USDA Forest Serv. Gen. Tech. Rep. INT-172. Ogden, Ut.

Haferkamp, M.R., D.C. Ganskopp, K.L. Marietta, and B.W. Knapp. 1990. Environmental influences on germination of utricles and seedling establishment of 'Immigrant' forage kochia. J. Range Manage. 43:518-522.

Harrison, R.D., N.J. Chatterton, B.L. Waldron, B.W. Davenport, A.J. Palazzo, W.H. Horton, and K.H. Asay. 2000. Forage kochia its compatibility and potential aggressiveness on Intermountain rangelands. Utah Agr. Exp. Sta. Res. Rept 162. 66 p.

Jorgensen, K.R. and J.N. Davis. 1984. A technique for retaining seed viability in Kochia prostrata, p. 166-167. In: A.R. Tiedemann, E.D. McArthur, H.C. Stutz, R. Stevens, and K.L. Johnson (compilers), Proc.-Symposium on the biology of Atriplex and related chenopods. USDA Forest Serv. Gen. Tech. Rep. INT-172. Ogden, Ut.

McArthur, E.D., B.C. Guinta, and A.P. Plummer. 1974. Shrubs for restoration of depleted ranges and disturbed areas. Utah Science 34:28-33.

McArthur, E.D., A.C. Blauer, and R. Stevens. 1990. Forage kochia competition with cheatgrass in central Utah, p. 56-65. In: E.D. McArthur, E.M. Romney, S.D. Smith, and P.T. Tueller (compilers), Proc.Symposium on cheatgrass invasion and shrub dieoff, and other aspects of shrub biology and management. USDA Forest Serv. Gen. Tech. Rep. INT-276. Ogden, Ut.

McArthur, E.D., S.C. Sanderson, and J.N. Davis. 1996. Adaptation of forage kochia accessions across an environmental gradient in Rush Valley, Utah. Arid Soil Research and Rehabilitation 10:125-138.

Monsen, S.B. and D. Turnipseed 1990. Seeding forage kochia into cheatgrass infested ranges, p. 66-71. In: E.D. McArthur, E.M. Romney, S.D. Smith, and P.T. Tueller (compilers), Proc.-Symposium on cheatgrass invasion and shrub dieoff, and other aspects of shrub biology and management. USDA Forest Serv. Gen. Tech. Rep. INT-276. Ogden, Ut.

National Oceanic and Atmospheric Administration (NOAA). 1993. Monthly weather records for Utah. Vol. 95 Num. 12. National Climate Data Center, Asheville, N.C.

National Oceanic and Atmospheric Administration (NOAA). 1994. Monthly weather records for Utah. Vol. 96 Nums. 1-4. National Climate Data Center, Asheville, N.C.

National Oceanic and Atmospheric Administration (NOAA). 1995. Monthly weather records for Utah. Vol. 97 Num. 1-4. National Climate Data Center, Asheville, N.C.

Pendleton R.L., N.C. Frischknecht, and E.D. McArthur. 1992. Long-term survival of 20 selected plant accessions in a Rush Valley, Utah, planting. USDA Forest Serv. Res. Note INT-403, Ogden, Ut. 7 p. 
Peters, E.F. and S.C. Bunting. 1994. Fire conditions and pre-and postoccurrence of annual grasses on the Snake River Plain, p. 31-36. In: S.B. Monsen, and S.G. Kitchen (compilers), Proc.-ecology and management of annual rangelands. USDA Forest Serv. Gen. Tech. Rep. INT-GTR-313. Ogden Ut.

Phillipi, T. and J. Seger. 1989. Hedging one's evolutionary bets, revisited. Trends in Ecology and Evolution 4:41-44.

Romo, J.T. and M.R. Haferkamp. 1987. Forage kochia germination response to temperature, water stress, and specific ions. Agron. J. 79:27-30.

SAS. 1998. SAS user's guide. SAS Institute, Cary, N.C.

Shishkin, B.K. (ed.). 1936. Flora of the U.S.S.R.. vol. vi, Centrospermae.Isdatel'stvo Akademii Nauk SSSR, Moscow (Translated from Russian, 1970, Smithsonian Inst. and Nat. Sci. Found., Washington, D.C.) 731 p.

Stevens, R. And E.D. McArthur. 1990. 'Immigrant' forage kochia competition with halogeton following various seeding techniques, p. 175-180. In: E.D. McArthur, E.M Romney, S.D. Smith, and P.T. Tueller (compilers), Proc.-symposium on cheatgrass invasion, shrub dieoff, and other aspects of shrub biology and management. USDA Forest Serv. Gen. Tech. Rep. INT-276. Ogden, Ut.
Stevens, R. And G.A. Van Epps. 1984. Seeding techniques to improve establishment of forage kochia [Kochia prostrata (L.) Schrad.] and fourwing saltbrush [Atriplex canescens (Pursh) Nutt.], p. 269-272. In: A.R. Tiedemann, E.D. McArthur, H.C. Stutz, R. Stevens, and K.L. Johnson (compilers), Proc.-Symposium on the biology of Atriplex and related chenopods. USDA Forest Serv. Gen. Tech. Rept. INT-172, Ogden, Ut.

Stevens, R., K.R. Jorgensen, E.D. McArthur, and J.N. Davis. 1985. 'Immigrant' forage kochia. Rangelands 7:22-23.

Stewart, A. 1998. 'Immigrant' forage kochia (Kochia prostrata) seed germination and viability as affected by commercial seed practices. Masters Thesis, Brigham Young University, Provo, Ut.

Waller, S.S., C.M. Britton, D.K. Schmidt, J. Stubbendieck, and F.A. Sneva. 1983. Germination characteristics of two varieties of Kochia prostrata (L.) Schrad. J. Range Manage. 36:242-245.

Whisenant, S.G. 1990. Changing fire frequencies on Idaho's Snake River Plains: ecological and management implications, p. 4-10. In: E.D. McArthur, E.M. Romney, S.D. Smith, and P.T. Tueller (compilers), Proc.symposium on cheatgrass invasion, shrub dieoff, and other aspects of shrub biology and management. USDA Forest Serv. Gen. Tech. Rept. INT-276. Ogden, Ut.
Young, J.A. 1994. History and use of semiarid plant communities-changes in vegetation, p. 5-8. In: S.B. Monsen, and S.G. Kitchen (compilers), Proc.- ecology and management of annual rangelands. USDA Forest Serv. Gen. Tech. Rep. INT-GTR-313. Ogden Ut.

Young, J.A., R.A. Evans, R. Stevens, and R.L. Everett. 1981. Germination of Kochia prostrata seed. Agron. J. 73:957-961. 